\title{
Erratum to: Inaccuracies About the MMPI-2 Fake Bad Scale in the Reply by Ben-Porath, Greve, Bianchini, and Kaufmann (2009)
}

Carolyn L. Williams • James N. Butcher •

Carlton S. Gass • Edward Cumella • Zina Kally

Published online: 5 December 2009

(C) Springer Science+Business Media, LLC. 2009

Erratum to: Psychol. Inj. and Law

DOI 10.1007/s12207-009-9046-3

The surname of Dr. Paul Kaufmann is misspelled in the title of the original publication.

The online version of the original article can be found under http://dx. doi.org/10.1007/s12207-009-9046-3.

C. L. Williams $(\triangle) \cdot$ J. N. Butcher

University of Minnesota,

Minneapolis, MN, USA

e-mail: willi001@umn.edu

J. N. Butcher

e-mail: butch001@umn.edu

C. S. Gass

Miami Veterans Affairs Healthcare System,

Miami, FL, USA

e-mail: carlton.gass@va.gov

E. Cumella $\cdot$ Z. Kally

Remuda Program for Eating Disorders,

Wickenburg, AZ, USA

E. Cumella

e-mail: edward.cumella@remudaranch.com

Z. Kally

e-mail: zina.kally@remudaranch.com 